\title{
High-Sensitivity Assays for C-Reactive Protein as a Systemic Inflammatory Marker in Assessing Asthma
}

I have selected this review by Ong as my Editor's Pick for this issue because there is a real interest in establishing an early diagnosis for asthma, but also in determining the risk level of severity regarding the underlying inflammatory process. This role could be played by using C-reactive protein, a very simple and relatively low-cost marker. This review EDITOR'S aims to explore the potential of this marker for determining the severity of disease, despite the fact that more studies should be undertaken to define the close relationship of those two concerns: inflammatory process and severity of the disease.

\section{Jacques Bouchard}

Associate Professor of Clinical Medicine, Université Laval; Head of the Medicine Department, La Malbaie Hospital, Quebec City, Canada

\section{Authors:}

Leong Tung Ong

Faculty of Medicine, University of Malaya, Kuala Lumpur, Malaysia

*Correspondence to leotungong@gmail.com

Disclosure:

The author has declared no conflicts of interest.

Received:

09.12 .20

Accepted:

11.02.21

Keywords:

Asthma, C-reactive protein (CRP), hypersensitivity inflammation, steroids.

Citation:

EMJ Allergy Immunol. 2021;6[1]:53-60.

\section{Abstract}

Asthma is a chronic inflammatory condition, and the main features include airway hyper-responsiveness and inflammation of the airway with the accumulation of inflammatory cells. Increased level of plasma fibrinogen and serum amyloid A suggests the involvement of systemic inflammation in asthma. C-reactive protein (CRP) is an acute-phase protein that produced mainly by hepatocytes and is an inflammatory marker. CRP levels monitoring is useful in the evaluation of early inflammation and efficacy of treatment in acute-phase illnesses. Several studies show that asthma alone can cause an increase in high-sensitivity CRP (hs-CRP) when compared with the healthy controls. Besides that, steroid-naïve patients have a higher mean value of hs-CRP levels compared with those on inhaled corticosteroid. Furthermore, studies have shown that an elevated hs-CRP level has a positive correlation with nonatopic asthma but not atopic asthma. Additionally, an increase in serum hs-CRP levels correlates with the severity of asthma. Therefore, serum hs-CRP is a useful surrogate marker to predict the severity of inflammation of the bronchus in asthma and assess the asthma status. 


\section{INTRODUCTION}

Asthma is a chronic inflammatory condition where the main physiological features include reversible airflow narrowing and systemic inflammation. ${ }^{1} \quad$ Airway hyper-responsiveness and inflammation of the airway with the accumulation of inflammatory cells are observed in mild and moderate asthma to severe asthma. ${ }^{2}$ Involvement of inflammatory cells such as neutrophils, eosinophils, mast cells, neutrophils, cytokines, and T-lymphocytes in asthma induce systemic inflammation. ${ }^{3}$ Increased level of plasma fibrinogen and serum amyloid A suggests the involvement of systemic inflammation in asthma. ${ }^{4}$ Severe inflammation and exacerbation occur in asthma occur due to narrowing of the airway, airway oedema, bronchial hyperresponsiveness, and hypersecretion which result from the remodeling process. ${ }^{2}$ Several studies have shown that the inflammatory process in asthma correlates with severity of disease and deterioration of pulmonary function. . 5-8 $^{2}$

C-reactive protein (CRP) is an acute-phase protein that is produced mainly by hepatocytes and is an inflammatory marker. ${ }^{9}$ IL-1, IL-6, and TNF-a are important cytokines that stimulate the activation of CRP. ${ }^{7} \quad \mathrm{LL}-6$ is involved in phosphorylation of the transcription factor through gene activation and thus promotes the synthesis of CRP.10, 11 Besides that, IL-1B stimulates the transcriptional events in the presence of IL- 6 which then activates CRP. ${ }^{12}$ IL- 6 has growthregulator factors which are involved in activation, growth, and differentiation of T-cells. ${ }^{7}$ Moreover, activation of CRP can stimulate the vascular smooth muscle cells to secrete more TNF-a. ${ }^{13}$ CRP is involved in complement activation and activation of phagocytic cells to eliminate bacteria and damaged cells. ${ }^{7}$ Increased CRP levels may indicate several conditions such as infection, cancer, and autoimmune conditions such as systemic lupus erythematosus and rheumatoid arthritis, and myocardial infarction. ${ }^{9}$ CRP levels monitoring is useful in the evaluation of early inflammation and efficacy of treatment in acute-phase illnesses. ${ }^{14}$ High-sensitivity assays for CRP (hs-CRP) which measures the very low amount of CRP in the blood (below $0.2 \mathrm{mg} / \mathrm{L}$ ) has been used to evaluate the systemic inflammation and prognostic marker for diabetes mellitus and cardiovascular diseases. ${ }^{2}$ A populationbased study by Kony et al. ${ }^{15}$ suggested that increased CRP levels are associated with higher frequency of bronchial hyper-responsiveness and respiratory impairment due to systemic inflammation. Therefore, hs-CRP could be used to detect systemic inflammation and the severity of asthma. The purpose of this paper is to evaluate the association between hs-CRP levels and patients diagnosed with asthma.

Table 1: High-sensitivity C-reactive protein levels in patients with asthma and controls.

\begin{tabular}{|c|c|c|c|c|c|}
\hline \multirow[t]{2}{*}{ Study } & \multirow[t]{2}{*}{ Study design } & \multicolumn{2}{|c|}{ Asthma group } & \multicolumn{2}{|c|}{ Healthy control } \\
\hline & & Patients (n) & $\begin{array}{l}\text { Hs-CRP level } \\
(\mathrm{mg} / \mathrm{L})\end{array}$ & Patients ( $n$ ) & $\begin{array}{l}\text { Hs-CRP level } \\
(\mathrm{mg} / \mathrm{L})\end{array}$ \\
\hline Galez et al., $2006^{16}$ & $\begin{array}{l}\text { Observational } \\
\text { study }\end{array}$ & 47 & 0.55 & 42 & 0.23 \\
\hline $\begin{array}{l}\text { Kasayama et al., } \\
2008^{5}\end{array}$ & $\begin{array}{l}\text { Observational } \\
\text { study }\end{array}$ & 329 & 0.44 & 1,684 & 0.40 \\
\hline $\begin{array}{l}\text { Pellizzaro et al., } \\
2010^{17}\end{array}$ & $\begin{array}{l}\text { Observational } \\
\text { study }\end{array}$ & 22 & $4.20 \pm 1.32$ & 27 & $1.74 \pm 4.67$ \\
\hline Kilic et al., $2012^{18}$ & $\begin{array}{l}\text { Observational } \\
\text { study }\end{array}$ & 30 & $1.97 \times 10^{-6}$ & 30 & $4.50 \times 10^{-6}$ \\
\hline Razi et al., $2012^{19}$ & $\begin{array}{l}\text { Observational } \\
\text { study }\end{array}$ & 108 & $5.47 \pm 7.33$ & 93 & $1.46 \pm 1.89$ \\
\hline $\begin{array}{l}\text { Shimoda et al., } \\
2015^{20}\end{array}$ & $\begin{array}{l}\text { Observational } \\
\text { study }\end{array}$ & 45 & $2.21 \times 0.39$ & 40 & $2.49 \times 0.41$ \\
\hline
\end{tabular}

Hs-CRP: high-sensitivity C-reactive protein. 


\section{METHODS}

A PubMed search was conducted using the $\mathrm{MeSH}$ terms "C-reactive protein" OR "systemic inflammation" AND "asthma" retrieving papers from January 2000-December 2020. Additional studies of interest were retrieved from the reference list of selected articles. The search yielded 214 original articles. The titles and abstracts of all studies were screened for their eligibility to be included in this review. A fulltext manuscript was examined when the decision could not be made on the basis of the title and abstract solely. A total of 19 articles were deemed relevant and were included in this review.

\section{C-REACTIVE PROTEIN IN PATIENTS WITH ASTHMA AND HEALTHY INDIVIDUALS}

Several studies have shown that serum levels of hs-CRP are increased compared with healthy controls (Table 1).5,16-20 Both systemic inflammation and airway inflammation may occur in asthma due to an increase in the concentration of acute-phase protein. ${ }^{21}$ A study by Jousilahti et al. showed that acute-phase proteins of systemic inflammation such as serum amyloid $A$ and plasma fibrinogen were positively associated with asthma prevalence. ${ }^{22}$

Additionally, the study by Büyüköztürk et al. also showed that the level of acute-phase reactant serum amyloid $A$ was significantly higher in patients diagnosed with asthma compared to healthy controls. ${ }^{21} \mathrm{Hs}$-CRP measurement may be used as an inflammatory marker to assess the severity of systemic inflammation asthma. 5,16,17,19 CRPs can activate macrophages by binding with Fc receptors for antibodies, and act on monocytes and neutrophils by interacting with CRP receptors on their surface..$^{19}$ Therefore, CRP can be a useful surrogate marker to assess subclinical, airway inflammation, and systemic inflammation in asthma. 5,16,17,19

The study by Sävykoski et al. ${ }^{23}$ suggested that serum hs-CRP levels were higher in patients with mild and moderate asthma compared to the healthy controls. ${ }^{23}$ Besides that, the study by $\mathrm{Wu}$ et al. ${ }^{24}$ demonstrated that hs-CRP level gradually increased in asthma of various severity from mild, moderate to severe in children. ${ }^{24} \mathrm{~A}$ population- based study by Shaaban et al. ${ }^{25}$ demonstrated that increase serum CRP levels over time were associated with a decrease in forced expiratory volume in 1 second $\left(F E V_{1}\right)$ and pulmonary function. ${ }^{25}$ Furthermore, Kony et al. ${ }^{15}$ showed that increased serum hs-CRP was associated with lower $\mathrm{FEV}_{1}{ }^{15}$ However, the study by Ramirez ${ }^{26}$ showed no significant correlation between hsCRP and asthma with mild severity. ${ }^{26}$

However, several other factors may contribute to the elevation of serum hs-CRP levels other than asthma. ${ }^{17}$ For example, obesity, cardiovascular diseases, atherosclerosis, diabetes mellitus, and ageing may elevate the hs-CRP levels whereas smoking cessation may reduce the hs-CRP levels. 17,19 Therefore, an increase in CRP level in patients with asthma may be caused by an underlying chronic inflammatory state of the patients or infections. ${ }^{17}$ Moreover, hs-CRP levels can be affected by the interval between the beginning of the asthma exacerbation and the sample collection for measurement. ${ }^{27}$ Hence, CRP is a sensitive but nonspecific marker of inflammation. ${ }^{28}$ Nevertheless, an increase in hs-CRP level in children is primarily attributed to respiratory allergic diseases because the prevalence of these risk factors is very low in children. ${ }^{7}$ Besides that, serum level C3 is elevated in children with asthma, and the serum C3 level has a positive correlation with the severity of asthma. ${ }^{29}$

Despite these confounding factors, results from several studies suggest that asthma alone can

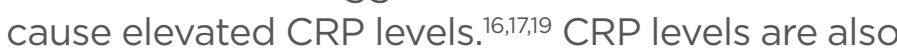
increased in patients with undiagnosed asthma even with the absence of pulmonary events. ${ }^{17}$

\section{C-REACTIVE PROTEIN IN STEROID- NAÏVE ASTHMA AND INHALED- CORTICOSTEROID ASTHMA}

Several studies demonstrated that steroid-naive patients have a higher mean value of hs-CRP compared to those on inhaled corticosteroid (ICS; Table 2).4,6,7,9,30-33 In a study by Takemura et al., ${ }^{4}$ serum levels of hs-CRP in steroid-naïve patients correlated positively with numbers of sputum eosinophils and negatively with indices of pulmonary function. However, no significant correlation was found between serum hs-CRP levels, pulmonary function, or sputum indices in steroid-inhaling patients. ${ }^{4}$ 
Table 2: High-sensitivity C-reactive protein levels in patients with steroid-naïve asthma and treated with inhaled corticosteroids.

\begin{tabular}{|l|l|l|l|l|l|}
\hline \multirow{2}{*}{ Study } & Study design & \multicolumn{2}{|l|}{ Steroid-naive asthma } & \multicolumn{2}{l|}{ Inhaled corticosteroid asthma } \\
\cline { 2 - 6 } & Patients (n) & $\begin{array}{l}\text { Hs-CRP level } \\
(\mathrm{mg} / \mathrm{L})\end{array}$ & Patients ( $\mathrm{n})$ & $\begin{array}{l}\text { Hs-CRP level } \\
(\mathrm{mg} / \mathrm{L})\end{array}$ \\
\hline $\begin{array}{l}\text { Takemura et al., } \\
2006^{4}\end{array}$ & $\begin{array}{l}\text { Observational } \\
\text { study }\end{array}$ & 22 & $1.30 \pm 1.5$ & 23 & $0.90 \pm 1.0$ \\
\hline Allam et al., 2009 & $\begin{array}{l}\text { Observational } \\
\text { study }\end{array}$ & 24 & $2.63 \pm 2.1$ & 26 & $2.35 \pm 1.66$ \\
\hline $\begin{array}{l}\text { Zietkowski et al., } \\
\text { 20097 }\end{array}$ & $\begin{array}{l}\text { Observational } \\
\text { study }\end{array}$ & 20 & $1.36 \pm 0.54$ & 19 & $1.07 \pm 0.28$ \\
\hline Deraz et al., 2011 & $\begin{array}{l}\text { Observational } \\
\text { study }\end{array}$ & 30 & 3.15 & 30 & 1.55 \\
\hline $\begin{array}{l}\text { Girdhar et al., } \\
2011^{30}\end{array}$ & $\begin{array}{l}\text { Observational } \\
\text { study }\end{array}$ & 30 & $48.0 \pm 60.0$ & 30 & $24.00 \pm 54.00$ \\
\hline $\begin{array}{l}\text { Halvani et al., } \\
2012^{31}\end{array}$ & $\begin{array}{l}\text { Observational } \\
\text { study }\end{array}$ & 30 & 3.32 & 31 & 2.60 \\
\hline $\begin{array}{l}\text { Hoshino et al., } \\
2014^{32}\end{array}$ & $\begin{array}{l}\text { Observational } \\
\text { study }\end{array}$ & 48 & 0.90 & 51 & 0.50 \\
\hline $\begin{array}{l}\text { Karthikeyan et al., } \\
2014^{33}\end{array}$ & $\begin{array}{l}\text { Observational } \\
\text { study }\end{array}$ & 18 & $0.93 \pm 1.18$ & 22 & $0.17 \pm 0.18$ \\
\hline
\end{tabular}

Hs-CRP: High-sensitivity C-reactive protein.

In a study by Zietkowski et al., ${ }^{7}$ serum hs-CRP levels in patients diagnosed with mild-tomoderate asthma treated with ICS was lower compared to steroid-naive mild asthma but there was no correlation with serum eosinophil cationic protein. ${ }^{7}$ However, the study by Allam et al. ${ }^{9}$ showed that serum hs-CRP level had a significant positive correlation with sputum eosinophil percentage. ${ }^{9}$ The contradictory results from different studies can occur due to non-compliance of medication, suboptimal doses of ICS, or development of asthma that resistant to steroids. ${ }^{9}$

Decreased CRP levels in patients treated with steroids can be due to the interaction between corticosteroids with IL-1B and IL- 6 which reduce the production of ILs. ${ }^{17}$ Corticosteroids inhibit the synthesis of IL-6 is induced by cytokines such as IL-1 $\beta$ and TNF-a. ${ }^{17,34}$ The study by Hashino and Nakamura ${ }^{35}$ demonstrated that inhaled beclomethasone dipropionate improved the symptoms of asthma and hyper-responsiveness by inhibiting the infiltration of inflammatory cells in the airway tissue. ${ }^{35}$ In addition, Sin et al. ${ }^{36}$ showed that discontinuation of inhaled fluticasone increased the serum CRP level in mild-to-moderate chronic obstructive pulmonary diseases. ${ }^{36}$ Therefore, based on the result of these studies, ICS should reduce the systemic inflammatory marker in asthma. ${ }^{31}$

Furthermore, a study by Kasayama et al. ${ }^{5}$ also suggested that prolonged ICSs treatment for 3 months reduces the plasma CRP levels significantly due to the clinical effect of corticosteroids on the inflammatory process of airway tissue. ${ }^{5}$ Deraz et al. $^{6}$ showed that serum hs-CRP had a sensitivity of $72 \%$ and a specificity of $93 \%$ in assessment of different grades of asthma severity and control. ${ }^{6}$

The study by Kadakal et al. $^{3}$ demonstrated that the hs-CRP decreased in post-treatment of corticosteroid in asthma compared to pretreatment where the hs-CRP levels pre-treatment and post-treatment were $4.7 \mathrm{mg} / \mathrm{L}$ and $2.1 \mathrm{mg} / \mathrm{L}$ respectively. ${ }^{3}$ This study also showed that the hs-CRP levels had a negative correlation with $F E V_{1}$ following corticosteroid treatment due to improved pulmonary function parameters and decreased hs-CRP levels. ${ }^{3}$ In addition, the 
study by Girdhar ${ }^{30}$ also showed that hs-CRP levels decreased after treatment in patients with asthma where the hs-CRP levels before and after treatment were $4.8 \pm 6.0 \mathrm{mg} / \mathrm{dL}$ and $2.4 \pm 5.4 \mathrm{mg} /$ $\mathrm{dL}$, respectively. ${ }^{30}$ Some studies did not show a significant decrease in hs-CRP level because of short duration and therapy, and inclusion of patients diagnosed with mild or moderate asthma where the inflammatory markers would be detected even at lower levels of inflammation. ${ }^{3}$ Qian et al. ${ }^{27}$ showed that hs-CRP is a sensitive marker only in cases of severe asthma. ${ }^{27}$ Patients with a $\mathrm{BMI}>25 \mathrm{~kg} / \mathrm{m}^{2}$, especially females, have a higher risk of developing moderate to severe degrees of asthma. ${ }^{30}$ The study by Boulet and Franssen $^{37}$ suggested that obese patients were less likely to achieve asthma control with ICS or ICS with a long-acting $\beta$-agonist compared to patients who were non-obese. ${ }^{37}$ All those factors may cause only slight reduction in hs-CRP levels after treatment.

\section{C-REACTIVE PROTEIN IN ATOPIC AND NON-ATOPIC ASTHMA}

The study by O'Lafsdottir et al. ${ }^{38}$ suggested that higher hs-CRP levels are associated with non-allergic asthma but not in allergic asthma. ${ }^{38}$ Besides that, hs-CRP levels were also affected by age, BMI, and smoking. ${ }^{38}$ The study by Sahoo et al. ${ }^{39}$ also showed that increase in hs-CRP levels was observed in non-atopic asthmatics but no association of increased hs-CRP in atopic asthmatics. ${ }^{39}$ The mean hs-CRP levels in atopic asthma and non-atopic asthma were 2.9 \pm 2.1 $\mathrm{mg} / \mathrm{L}$ and $8.3 \pm 2.5 \mathrm{mg} / \mathrm{L}$ respectively, in the study. ${ }^{39}$ Furthermore, the study by Butland et al., also demonstrated that hs-CRP levels had a positive correlation with non-atopic asthma but not atopic asthma. ${ }^{4}$

Lack of correlation between hs-CRP and atopic asthma suggests that the mechanism underlying the bronchial hyperresponsiveness is different. ${ }^{38}$ The study by Lúdvíksdóttir et al. showed that atopic asthma was more hyper-responsive to adenosine $5^{\prime}$ '-monophosphate (AMP) compared to non-atopic asthma. ${ }^{41}$ Another study by Lúdvíksdóttir et al., showed that atopic asthma had higher levels of exhaled nitrogen oxide compared to non-atopic asthma. ${ }^{42}$ Moreover, the study by Amin et al. showed that the number of eosinophils, T-lymphocytes (CD3-, CD4-, CD8CD-25-positive cells), IL-4, and IL-5 increased more significantly in atopic asthma compared to non-atopic asthma. ${ }^{43}$ Furthermore, atopic asthma has a higher degree of epithelial damage compared to non-atopic asthma. ${ }^{43}$ Negative correlation between hs-CRP levels and atopic asthma suggest that the systemic inflammatory process in atopic asthma is low. ${ }^{38}$

The study by Wood et al. demonstrated that asthmatic patients with neutrophilic airway inflammation had increased systemic inflammation. ${ }^{44}$ Therefore, CRP can be a systemic marker for patients with neutrophilic asthma. ${ }^{44}$ Moreover, the study by Ko et al., also reported that hs-CRP had a significant association with patients with asthma with high neutrophil and low eosinophils. ${ }^{36}$ The study also showed that hs-CRP levels were correlated with small airway obstruction in patients diagnosed with neutrophilic asthma. ${ }^{45}$ Inflammatory mediators results from inflammation or repair mechanisms may 'spill-over' into circulation which may lead to systemic inflammation. ${ }^{46} \mathrm{Fu}$ et al showed that systemic inflammation in neutrophilic asthma had altered genes involved in IL-1, TNF-a/ nuclear factor-kB, and Kit receptor pathways which were associated with immune response, inflammatory responses, and defense. ${ }^{47}$ Furthermore, Wood et al. showed that patients with neutrophilic asthma had increased receptors a for IL-8 (IL-8-RA) which are highly selective for neutrophil chemotaxis. ${ }^{44}$ Meanwhile, there were several studies suggested that there was no correlation between hs-CRP level with history of atopy, eosinophilia inflammation, and allergic sensitisation. ${ }^{4,31,44}$

\section{C-REACTIVE PROTEIN IN PREDICTING ASTHMA CONTROL}

Four studies showed that serum hs-CRP increases with the severity of asthma and the highest among patients with poorly controlled and exacerbating asthma (Table 3). 18,26,48,49 However, studies by Ramirez et al. and Sigari et al. demonstrated no significant correlation between hs-CRP levels and clinical indices of asthma control.26,50 The studies by Fujita et al. and Al Obaidi et al. classified patients to stable asthma and exacerbating asthma, the study by Ramirez et al. classified the patients according to the National Asthma Education and Prevention Program (NAEPP) control scores..$^{51}$ 
Table 3: Correlation between high-sensitivity C-reactive protein levels and asthma control.

\begin{tabular}{|l|l|l|l|l|l|l|l|}
\hline \multirow{2}{*}{ Study } & \multirow{2}{*}{ Study design } & \multicolumn{2}{l|}{ Well-controlled asthma } & \multicolumn{2}{l|}{ Partly controlled asthma } & \multicolumn{2}{l|}{$\begin{array}{l}\text { Poorly controlled or } \\
\text { exacerbating asthma }\end{array}$} \\
\cline { 3 - 8 } & Patients (n) & $\begin{array}{l}\text { Hs-CRP level } \\
(\mathrm{mg} / \mathrm{L})\end{array}$ & Patients (n) & $\begin{array}{l}\text { Hs-CRP level } \\
(\mathrm{mg} / \mathrm{L})\end{array}$ & Patients (n) & $\begin{array}{l}\text { Hs-CRP level } \\
(\mathrm{mg} / \mathrm{L})\end{array}$ \\
\hline $\begin{array}{l}\text { Fujita et al., } \\
2007^{48}\end{array}$ & $\begin{array}{l}\text { Observational } \\
\text { study }\end{array}$ & NA & 0.473 & NA & NA & NA & 0.908 \\
\hline $\begin{array}{l}\text { Al Obaidi et } \\
\text { al., } 2013^{49}\end{array}$ & $\begin{array}{l}\text { Observational } \\
\text { study }\end{array}$ & 126 & 16.970 & NA & NA & 52 & 225.230 \\
\hline $\begin{array}{l}\text { Ramirez et } \\
\text { al., } 2010^{26}\end{array}$ & $\begin{array}{l}\text { Observational } \\
\text { study }\end{array}$ & 27 & 2.040 & NA & NA & 27 & 1.990 \\
\hline $\begin{array}{l}\text { Kilic et al., } \\
2012^{18}\end{array}$ & $\begin{array}{l}\text { Observational } \\
\text { study }\end{array}$ & 7 & $0.700 \times 10^{-6}$ & NA & NA & 23 & $2.2 \times 10^{-6}$ \\
\hline $\begin{array}{l}\text { Sigari et al., } \\
2013^{50}\end{array}$ & $\begin{array}{l}\text { Observational } \\
\text { study }\end{array}$ & 59 & 10.600 & 30 & 11.41 & 11 & 11.200 \\
\hline $\begin{array}{l}\text { Monadi et al., } \\
2016^{2}\end{array}$ & $\begin{array}{l}\text { Observational } \\
\text { study }\end{array}$ & 80 & $1.980 \pm 1.700$ & NA & NA & 40 & $3.300 \pm 3.100$ \\
\hline
\end{tabular}

Hs-CRP: High-sensitivity C-reactive protein; NA: not available.

The study by Sigari et al. classified the patients according to Global Initiative for Asthma (GINA) control ${ }^{52}$ and the studies by Kilic et al. and Monadi et al. classified the patients according to Asthma Control Test (ACT). ${ }^{53}$

The management goals of patients diagnosed with include suppression of airway inflammation and the achievement of well-controlled asthma. ${ }^{54}$ ICS treatment was associated with decreased hs-CRP levels and therefore serum hs-CRP levels may be used to differentiate between poorlycontrolled asthma and well-controlled asthma. ${ }^{2}$ However, the study by Ramirez et al. suggested that there was no correlation between hsCRP level with wheeze, the National Asthma Education and Prevention Program (NAEPP) control score, fractional exhaled nitric oxide, and $\mathrm{FEV}_{1}{ }^{26}$ The study by Khalili et al. also showed that the fractional exhaled nitric oxide level was not associated with asthma control based on Asthma Control Questionnaire (ACQ). ${ }^{55}$ Nevertheless, a study by Hancox et al. demonstrated that CRP level had a negative correlation with FEV and forced vital capacity. ${ }^{56}$ Moreover, two observational studies have shown that hs-CRP levels have a positive correlation with the severity of asthma. ${ }^{23,27}$ A study by Tonelli et al. also demonstrated that hs-CRP levels are significantly higher in patients with severe asthma compared to patients without any respiratory symptoms. ${ }^{57}$

Several studies showed that hs-CRP can be used as a surrogate marker for evaluation and monitoring of asthma, estimation of disease severity, and response to corticosteroid therapy. $2,3,7,15$ The synthesis rate of CRP reaches highest at around 48 hours and the CRP level decreases rapidly after the pathology ceases. ${ }^{50}$ Elevation levels of hs-CRP in well-controlled asthma compared to healthy controls suggest that the continuous eosinophilic inflammation. ${ }^{49}$ Several studies have shown that patients diagnosed with asthma are likely to have higher CRP concentrations compared to individuals who were diagnosed formerly with asthma or never had asthma. ${ }^{56,58}$ Moreover, two studies have shown that increase levels of hs-CRP are associated with respiratory symptoms of asthma such as wheeze, dyspnoea after effort, and nocturnal cough. ${ }^{15,38}$ Therefore, patients with asthma with exacerbation or that is poorly controlled may have elevated CRP concentration compared to patients with stable asthma or healthy control. ${ }^{50}$ 
The study by Kony et al. showed that higher frequency of bronchial hyper-responsiveness was associated with higher CRP levels while $\mathrm{FEV}_{1}$ had a negative correlation with CRP. ${ }^{15}$ The study by Fujita et al., demonstrated the serum hs-CRP levels have a positive correlation with the degree of airway obstruction as measured by $\mathrm{FEV}_{1} / \mathrm{FVC}^{48}$ Furthermore, the study by $\mathrm{Al}$ Obaidi et al. showed that patients diagnosed with asthma who had frequent bronchial hyperresponsiveness or reduced $\mathrm{FEV}_{1}$ tend to have both local inflammation in the bronchus and systemic inflammation. ${ }^{49}$ Therefore, increased CRP levels are associated with impairment of $\mathrm{FEV}_{1}$, decline of lung function, and high frequency of bronchial hyper-responsiveness. ${ }^{49}$

Several studies have shown that hs-CRP levels are correlated with asthma control.18,26,48,49 Therefore, hs-CRP levels can be used as an adjunct in assessment of asthma control in routine clinic follow-up since measurement is relatively simple and non-invasive. ${ }^{18}$ Moreover, hsCRP can be a marker for systemic inflammation that reflects on the control of the patient's symptoms and severity. ${ }^{18}$ Furthermore, hs-CRP level can also be used as a clinical indicator for dosage of ICSs and disease management. ${ }^{18}$ However, hs-CRP levels in some patients during asthma exacerbation remains unchanged or decreased compared with the levels during asymptomatic period. ${ }^{48}$ Several infectious and inflammatory conditions may alter the hs-CRP levels which may impair it's the accuracy as an indicator for asthma control. ${ }^{27}$ Therefore, hsCRP level may be used as an additional clinical marker for asthma control in routine follow-up but not during asthma exacerbation in acute settings because it is not specific. Hs-CRP can be used as a tool for monitoring the asthma status but is not recommended for the diagnosis of asthma. Further longitudinal research is required to compare the efficacy and accuracy of hs-CRP levels with other investigations such as arterial blood gas, peak flow, and pulse oximetry in assessing asthma exacerbation. Further follow-up cohort studies are warranted by assessing asthma control periodically and measuring hs-CRP levels prospectively to confirm the correlation.

\section{CONCLUSION}

In conclusion, an increase in hs-CRP level in asthmatic patients suggest that asthma involves systemic inflammation rather than the location inflammation of the airway. ICS can reduce the local inflammation of the airway and systemic inflammation where the level of hs-CRP shows reduction after treatment. Additionally, a high hs-CRP level is associated with a decline in pulmonary function and increased sputum eosinophils. Moreover, increased hs-CRP level has a significant association with non-atopic asthma and severity of respiratory symptoms but not with atopic asthma. Nevertheless, serum hs-CRP is an effective surrogate marker to predict the severity of inflammation of the bronchus in asthma. Furthermore, hs-CRP can be used as a marker to assess asthma status because increased serum hs-CRP has a positive correlation with the severity of asthma. Hence, serum hs-CRP can serve as an effective marker to assess the control and severity of asthma and response to treatment.

\section{References}

1. Wouters EF. The systemic face of airway diseases: the role of C-reactive protein. Eur Respir J. 2006;27(5):8779.

2. Monadi M et al. Serum C-reactive protein in asthma and its ability in predicting asthma control, a casecontrol study. Caspian J Intern Med 2016;7(1):37-42.

3. Kadakal F et al. The assessment of high sensitivity $\mathrm{C}$-reactive protein as a systemic marker in moderate asthma patients and changing levels by inhaled corticosteroids. J Pak Med Assoc. 2013;63(7):893-8.

4. Takemura $M$ et al. High sensitivity
C-reactive protein in asthma. Eur Respir J. 2006;27(5):908.

5. Kasayama $\mathrm{S}$ et al. Asthma is an independent risk for elevation of plasma C-reactive protein levels. Clinica Chimica Acta. 2009;399(1):7982.

6. Deraz TE et al. High-sensitivity C reactive protein as a biomarker for grading of childhood asthma in relation to clinical classification, induced sputum cellularity, and spirometry. Pediatr Pulmonol. 2012;47(3):220-225.

7. Zietkowski $Z$ et al. High-sensitivity $\mathrm{C}$-reactive protein in the exhaled breath condensate and serum in stable and unstable asthma. Respir Med. 2009;103(3):379-85.

8. Popov TA et al. Real life clinical study design supporting the effectiveness of extra-fine inhaled beclomethasone/formoterol at the level of small airways of asthmatics. Pulm Pharmacol Ther. 2013;26(6):624-9.

9. Allam $\mathrm{MH}$ et al. High sensitivity C-reactive protein: Its correlation with sputum cell counts in bronchial asthma. Respir Med. 2009;103(12):1878-84.

10. Agrawal A et al. Transactivation of 
C-Reactive Protein by IL-6 Requires Synergistic Interaction of CCAAT/ Enhancer Binding Protein $\beta$ (C) EBPB) and Rel p50. J Immunol. 2001;166(4):2378.

11. Jones SA et al. C-reactive protein: a physiological activator of interleukin 6 receptor shedding. J Exp Med. 1999;189(3):599-604.

12. Zhang $\mathrm{D}$ et al. The effect of interleukin-1 on C-reactive protein expression in Hep3B cells is exerted at the transcriptional level. Biochem J. 1995;310 ( Pt 1)(Pt 1):143-148.

13. Liu $\mathrm{N}$ et al. C-reactive protein induces TNF-a secretion by p38 MAPKTLR4 signal pathway in rat vascular smooth muscle cells. Inflammation. 2011:34(4):283-90.

14. Tall AR. C-reactive protein reassessed. N Engl J Med. 2004;350(14):1450-2.

15. Kony $\mathrm{S}$ et al. Association of bronchial hyperresponsiveness and lung function with C-reactive protein (CRP): a population based study. Thorax. 2004;59(10):892-6

16. Galez D et al. C-reactive protein in children with asthma and allergic rhinitis. Biochemia Medica. 2006;16(2):163-9.

17. Pellizzaro AM et al. C-reactive protein levels are elevated in asthma and asthma-like conditions. Clin Lab Sci. 2010;23(4):223.

18. Kilic $\mathrm{H}$ et al. The relationship between hs-CRP and asthma control test in asthmatic patients. Allergol Immunopathol (Madr). 2012;40(6):362-7.

19. Razi E, et al. Evaluation of highsensitivity C-reactive protein in acute asthma. Tanaffos. 2012;11(1):32-7.

20. Shimoda T et al. Serum highsensitivity C-reactive protein can be an airway inflammation predictor in bronchial asthma. Allergy Asthma Proc. 2015;36(2):e23-8

21. Büyüköztürk $S$ et al. Acute phase reactants in allergic airway disease. Tohoku J Exp Med. 2004;204(3):20913.

22. Ousilahti $P$, et al. The association of sensitive systemic inflammation markers with bronchial asthma. Ann Allergy Asthma Immunol. 2002;89(4):381-5.

23. Sävykoski T et al. Chlamydia pneumoniae infection and inflammation in adults with asthma. Respiration. 2004;71(2):120-5.

24. Wu SH et al. Reversed changes of lipoxin A4 and leukotrienes in children with asthma in different severity degree. Pediatr Pulmonol. 2010;45(4):333-40.

25. Shaaban $\mathrm{R}$ et al. Change in C-reactive protein levels and FEV1 decline: a longitudinal population-based study. Respir Med. 2006;100(12):2112-20.

26. Ramirez $D$ et al. Assessment of high-sensitivity $\mathrm{C}$-reactive protein as a marker of airway inflammation in asthma. Ann Allergy Asthma Immunol. 2010;104(6):485-9.

27. Qian F-H et al. High-sensitivity C-reactive protein: A predicative marker in severe asthma. Respirology. 2008;13(5):664-69.

28. Black $\mathrm{S}$ et al. C-reactive Protein. J Biol Chem. 2004;279(47):48487-90.

29. Abdel Fattah $M$ et al. Complement components (C3, C4) as inflammatory markers in asthma. Indian J Pediatr. 2010:77(7):771-3.

30. Girdhar A et al. Systemic inflammation and its response to treatment in patients with asthma. respiratory care. 2011;56(6):800.

31. Halvani A et al. Evaluation of correlation between airway and serum inflammatory markers in asthmatic patients. Lung India. 2012;29(2):143-146.

32. Hoshino $M$ et al. Increased C-reactive protein is associated with airway wall thickness in steroid-naive asthma. Ann Allergy Asthma Immunol. 2014;113(1):37-41.

33. Karthikeyan R et al. Effect of inhaled corticosteroids on systemic inflammation in asthma. Perspect Clin Res. 2014;5(2):75-9.

34. Ceciliani F et al. The systemic reaction during inflammation: the acute-phase proteins. Protein Pept Lett. 2002;9(3):211-23.

35. Hoshino $M$ et al. Anti-inflammatory effects of inhaled beclomethasone dipropionate in nonatopic asthmatics. Eur Respir J. 1996;9(4):696-702.

36. Sin DD et al. Effects of fluticasone on systemic markers of inflammation in chronic obstructive pulmonary disease. Am J Respir Crit Care Med. 2004;170(7):760-5.

37. Boulet LP et al. Influence of obesity on response to fluticasone with or without salmeterol in moderate asthma. Respir Med. 2007:101(11):2240-7.

38. Ólafsdottir IS et al. C reactive protein levels are increased in non-allergic but not allergic asthma: a multicentre epidemiological study. Thorax. 2005:60(6):451.

39. Sahoo RC et al. A study of highsensitivity $\mathrm{C}$-reactive protein in bronchial asthma. Indian J Chest Dis Allied Sci. 2009:51(4):213-6.

40. Butland BK et al. C-reactive protein, obesity, atopy and asthma symptoms in middle-aged adults. Eur Respir J. 2008;32(1):77.

41. Lúdvíksdóttir $D$ et al. Different airway responsiveness profiles in atopic asthma, nonatopic asthma, and Sjögren's syndrome. Allergy. 2000:55(3):259-65.

42. Lúdvíksdóttir D et al. Exhaled nitric oxide and its relationship to airway responsiveness and atopy in asthma. BHR-Study Group. Respir Med.
1999:93(8):552-6.

43. Amin $\mathrm{K}$ et al. Inflammation and structural changes in the airways of patients with atopic and nonatopic asthma. BHR Group. Am J Respir Crit Care Med. 2000;162(6):2295-301.

44. Wood LG et al. The neutrophilic inflammatory phenotype is associated with systemic inflammation in asthma. Chest. 2012;142(1):86-93.

45. Ko AR et al. High-sensitivity C-reactive protein can reflect small airway obstruction in childhood asthma. Yonsei Med J. 2016;57(3):690-7.

46. Barnes PJ et al. Systemic manifestations and comorbidities of COPD. Eur Respir J. 2009;33(5):116585.

47. $\mathrm{Fu} \mathrm{JJ}$ et al. Systemic inflammation is associated with differential gene expression and airway neutrophilia in asthma. Omics. 2013;17(4):187-99.

48. Fujita $M$, et al. C-reactive protein levels in the serum of asthmatic patients. Ann Allergy Asthma Immunol. 2007;99(1):48-53.

49. Alobaidi A et al. Association Between C Reactive Protein and Asthma. Turk Thorac J. 2010;11.

50. Sigari $\mathrm{N}$ et al. Correlation between hs-CRP and Asthma Control Indices. Tanaffos. 2013;12(3):44-48.

51. 2020 Focused Updates to the Asthma Management Guidelines: A Report from the National Asthma Education and Prevention Program Coordinating Committee Expert Panel Working Group. J Allergy Clin Immunol 2020;146(6):1217-70.

52. Global Initiative for Asthma (GINA) Global strategy for asthma management and prevention 2009 Available at: http://www.ginasthma. org. Last accessed: 23 June 2020.

53. Nathan RA et al. Development of the asthma control test: a survey for assessing asthma control. J Allergy Clin Immunol. 2004;113(1):59-65.

54. Khalili B et al. Discrepancy between clinical asthma control assessment tools and fractional exhaled nitric oxide. Ann Allergy Asthma Immunol. 2008;101(2):124-9.

55. Hancox RJ et al. Systemic inflammation and lung function in young adults. Thorax. 2007;62(12):1064-8.

56. Ford ES. The epidemiology of obesity and asthma. J Allergy Clin Immunol. 2005;115(5):897-909; quiz 910.

57. Tonelli $\mathrm{M}$ et al. Predictors of symptom recurrence after low-dose inhaled corticosteroid cessation in mild persistent asthma. Respir Med. 2006;100(4):622-629

58. Ford ES. Asthma, body mass index, and C-reactive protein among US adults. J Asthma. 2003;40(7):733-9. 